\title{
Extraction, Indigenous Dispossession, and State Power: Lessons from Standing Rock and Wet'suwet'en Resistance
}

\author{
Paarth Mittal ${ }^{1}$ \\ paarth_mittal@yahoo.ca
}

\begin{abstract}
When Indigenous-led resistance to land- and water-killing projects threatens extraction, settlercolonial state and corporate institutions use security mechanisms to eliminate such "threats." Using as case studies the pipeline conflicts of the Wet'suwet'en Nation's (especially Unist'ot'en Camp's) resistance to Coastal GasLink (CGL) in British Columbia (BC), Canada, and the Standing Rock Sioux Tribe's resistance to the Dakota Access Pipeline (DAPL) in North Dakota, United States (US), this paper explores how fossil-fuel extraction interacts with critical infrastructure (CI) securitization to further Indigenous land dispossession. I argue that although the Wet'suwet'en and Standing Rock cases both involved the state and corporations criminalizing Indigenous resistance to extraction - to uphold fossil-fuel capital interests - the Wet'suwet'en case is unique because Canadian actors attempted to pacify resistance through symbolic appeals to Indigenous rights. Indigenous communities across the world are violently oppressed for peacefully defending their water, land, and communities. However, the motives and strategies of violence are unique for every colonial jurisdiction exercising violence, and for every Indigenous community impacted. I compare and contrast the rationales and strategies of both cases through an in-depth content analysis of passages from TigerSwan surveillance and BC Supreme Court injunction documents. I discuss my findings within theoretical debates on dispossession and securitization.
\end{abstract}

Keywords: Wet'suwet'en First Nations; Standing Rock Sioux Tribe; pipelines; dispossession; securitization

\footnotetext{
${ }^{1}$ I would like to acknowledge with gratitude, as a settler, that this research was conducted on the traditional and unceded territories of the WSÁNEĆ, ləkं ${ }^{w}$ əə⿱一𫝀) also like to thank Dr. James (Jamie) Lawson for his thoughtful supervision of my research and writing process. Further, I would like to thank Dr. Marlea Clarke and all the students of the 2021 UVic Political Science Honours class for their feedback. This research was supported by the Jamie Cassels Undergraduate Research Award (JCURA), provided by the University of Victoria Learning and Teaching Support and Innovation (LTSI).
} 


\section{Extraction, Indigenous Dispossession, and State Power: Lessons from Standing Rock and Wet'suwet'en Resistance}

First Nations in present-day "North America" - known by many Nations as "Turtle Island" and other names with unique place-based meanings - have endured and resisted the European settler-colonial legacies of Indigenous land dispossession, destruction, displacement, and cultural and political genocide for over 500 years. This paper focuses on one aspect of colonialism, and aims to answer the following question: How do resource extraction and securitization interact to further the dispossession of Indigenous lands? To answer this question, I analyzed two recent case studies of Indigenous communities resisting fossil-fuel pipeline projects from either side of the Canada/US border: Wet'suwet'en vs. Coastal GasLink (CGL) and Standing Rock vs. Dakota Access Pipeline (DAPL).

This article argues that while security actions in both the Wet'suwet'en and Standing Rock cases were guided by a common rationale of criminalizing Indigenous resistance to extraction, to the benefit of fossil-fuel capital interests, the Wet'suwet'en case is unique because settler state and corporate actors attempted to pacify resistance through "benevolent" appeals to Indigenous rights. Why is a comparison of two recent pipeline conflicts significant for understanding how extraction and securitization interact to further Indigenous land dispossession? Indigenous peoples across the world are struggling to protect their lands and waters from industrial extraction and are subjected to violence in the process (Temper, 2019, p. 96). Nevertheless, the rationales and strategies of the settler state and corporate world (inflicting the violence) vary across jurisdictional boundaries and for the Indigenous communities affected. As a settler of colour, I undertook this research in order to investigate the systemic workings and motives of settler-colonial institutions and to better understand the complex ways through which they justify the suppression of Indigenous landdefence movements. My aim is to provide students - especially those interested in questions of environmental sustainability, Indigenous rights, social justice, politics, law, and activism-an insight on some material (or economic), racialized, and political power-related dimensions interlinked with contemporary environmental issues. Furthermore, this research is significant because it provides an analysis of settler-colonial security narratives central to the "Wet'suwet'en versus CGL" dispute, an area under-studied by previous academic scholarship due to the recency of this conflict.

I achieve my purposes through a four-step process. First, in the following two sections, I provide a brief historical context of dispossession and securitization for the Wet'suwet'en and Standing Rock peoples. Second, I introduce the methods and theoretical approaches that underly my research. Third, I introduce my findings on the rationales of securitization in both cases, followed by a discussion comparing the cases and linking evidence from security and court injunction documents to previous decolonial and Marxist scholarship on dispossession and securitization. Fourth, I introduce my findings on the specific strategies of securitization in both cases, followed by a discussion highlighting comparisons and linking the evidence to theoretical scholarship. Finally, I conclude my essay by outlining potential directions for future research. 


\section{Historical Context of Dispossession}

This paper's understanding of dispossession is grounded in the concept of "accumulation by dispossession" (AbD), which David Harvey refers to as

the continuation and proliferation of accumulation practices... 'primitive' or 'original' during the rise of capitalism...includ[ing]...commodification and privatization of land...[, and] colonial, neocolonial, and imperial processes of appropriation of assets (including natural resources). (Harvey, 2005, p.159)

Connected to AbD is the enclosure of the commons, which Karl Marx (1867/1976), in Chapter 27 of his text Capital, defines as a process whereby the ownership/stewardship of commonly held resources (i.e., land) are violently transferred to the private ownership of the capitalist class or bourgeoisie, the ruling elite. This paper uses a revised conception of enclosure, which scholars such as Glen Coulthard (2014) and Dorothy Kidd (2020) extend from original Marxist references to European peasants, to phenomena wherein Indigenous peoples are colonially dispossessed of their commonly stewarded resources (in this case, lands and rivers). Such enclosure later opens space for capitalist modes of production and, consequently, the privatized ownership of resource wealth by elites.

Indeed, the Standing Rock Sioux, and other Tribes of the Oceti Sakowin (Lakota for "Seven Council Fires") or "Great Sioux Nation," were subjected to such processes of dispossession and enclosure of lands. This began with the 1803 Missouri River "acquisition," when the US sent two white explorers, Lewis and Clark, to map and claim territory near the river; the US illegally "purchased" 827 million acres of Oceti Sakowin territory from the French Crown of Louisiana without the consent of Indigenous Nations (Estes, 2017, p.116). Over the two decades following the Oceti Sakowin's rejection of the Missouri River "acquisition" claim, dispossession took the form of violent US-led military operations against the Tribes (Estes, 2017, p.116); abolition of treaty-making and the nullification of the 1850 and 1868 Fort Laramie Treaties (signed between the US and Sioux Tribes) (Estes, 2017, p.116; Fort Laramie Treaty, 1851; Fort Laramie Treaty 1868); and the encroachment and exploitation of Oceti Sakowin lands for the development of industries such as fur, cattle, and gold (Kidd, 2020, p. 238). Like the Oceti Sakowin, the Wet'suwet'en and other First Nations in northwest BC have also experienced violent colonial dispossession. Since the 1850s, Wet'suwet'en and Gitxsan subsistence economies and land relationships came under increased pressures from industries such as gold, logging, and road and rail construction (Daly, 2005, pp.129-131). How do these practices connect to dispossession? In the contexts of both the Oceti Sakowin and Wet'suwet'en peoples, such economic transformations, pursued by the state and corporations for accumulating resource wealth, have disrupted Indigenous peoples' physical and spiritual connections to their land and natural environment, while also subjugating Indigenous ways of economic organization to those favoured by the settler-colonial state (Estes, 2017, p. 116; Kidd, 2020, p. 238; Office of the Wet'suwet'en [OOW], 2014, p. 105).

In the present day, as the motives of dispossession have shifted towards the development of the fossil-fuel industry, the Standing Rock and Wet'suwet'en peoples resist the forceful construction of oil and gas infrastructure on their lands. For the settler-colonial state, this has necessitated the development of strategies to "weed out" Indigenous "obstacles" to fossil-fuel infrastructure, which is further elaborated upon in the next section. 


\section{Context of Securitization and Surveillance}

How did the settler state and corporations facilitate the dispossession of Indigenous lands? A key mechanism they have utilized (and continue to utilize) is the securitization of critical infrastructure $(\mathrm{CI})$. This process is carried out through constructing Indigenous land-defence movements as "threats" to the settler state order, through surveilling the actions of such movements, and through using the coercive power of the state.

The history of this application of securitization, leading up to settler state security responses to Wet'suwet'en resistance, can be traced to the origins of the modern Canadian settler state. In the 1880s, Canadian federal government agencies - such as the Department of Indian Affairs (DIA) and the North West Mounted Police (NWMP) - created surveillance programs aimed at eliminating all threats to the expansion of the settler-colonial state in northwest Canada (Monaghan, 2013, p. 496). Jeffrey Monaghan's analysis of the DIA's correspondence on leaders of the pan-Indigenous movement, led by DIA agent Peter Ballendine, finds that the NWMP employed "othering" practices that justified the surveillance and arrest of groups of people opposed to colonization. Security agencies discriminated between "Good Indians"- native people who adopted colonially imposed practices of European liberalism - and "Bad Indians"- native people who resisted European settler colonialism (Monaghan, 2013, pp. 488, 492). Indeed, Monaghan's research highlights that the authorities undertook this project as part of a broader effort to eliminate "dangers" and "threats" to the settler-colonial acquisition of Indigenous territory (pp. 503-504).

Such logics manifested themselves in the Royal Canadian Mounted Police's (RCMP's) 2014-15 surveillance project SITKA, which was initiated to control, collect information on, and analyze the risk of groups and/or individuals associated with Indigenous protests related to many issues, such as resource extraction (Howe \& Monaghan, 2018, p. 333; RCMP, 2015, p. 4). Specifically, the RCMP aimed to collect information on "individuals and/or groups (Aboriginal and non-Aboriginal)...willing and capable of utilizing unlawful tactics...[associated] with Aboriginal public order events in Canada" (Howe \& Monaghan, 2018, p. 333; RCMP, 2015, p. ii); the Unist'ot'en Camp was one group under the surveillance of Project SITKA. Project SITKA surveilled Indigenous land-defenders in a variety of ways, using specific strategies, including aggregating protestors' personal information from police data banks and analyzing a variety of events (i.e., ceremonial dances, direct action training camps) and protest participants deemed to have potential "criminality risk" (Howe \& Monaghan, 2018, pp. 333-334; RCMP, 2015, pp. iixviii, pp. 10, 13, 24). Because such information was collected before the "crime" (of disrupting CI) was committed, it is clear that Project SITKA was intended for creating a "pre-crime" wealth of intelligence that enables effective response to anticipated disruptions/threats (Howe \& Monaghan, 2018, p. 342).

Similar to the context of securitization leading up to Wet'suwet'en resistance to CGL, the securitization of DAPL was also preceded by a context where the US criminalized Indigenous and environmentalist resistance to fossil-fuel development as "national security threats." Of particular importance is the security context in the aftermath of the September 11, 2001 attacks (also known as "post-9/11"), when the US and Canada were guided by a sense that the Western way of life was under attack and measures to curtail such supposed threats needed to be kept secret. The post-9/11 security context was marked by developments such as corporations and US security agencies labelling Indigenous and environmentalist activists as "eco-terrorists," and the passage of the 2001 
Patriot Act in the US, which increased security budgets and allowed surveillance methods such as wiretapping (Plotnikoff, 2020, pp. 14-16). Similar to RCMP surveillance efforts in Canada, the US Patriot Act is guided by a working definition of CI - infrastructure vital for the security, health, and safety of the US - that has expanded over time to include a broad range of sectors (i.e., energy), which are $85 \%$ owned by the private sector (Plotnikoff, 2020, pp. 17-18). As I illustrate in later sections, such post-9/11 rationales and strategies of intelligence-sharing were integral to TigerSwan's security operations to protect DAPL.

\section{Methods}

To answer my research question, I conducted a content analysis of the following publicly available primary sources: CGL's Notice of Application for Injunction (CGL v. Huson, 2018); the 2019 injunction granted to CGL by the Supreme Court of British Columbia (or "BC Supreme Court") (CGL v. Huson, 2019); seven internal situation reports (SITREPs) on DAPL-related surveillance by US private security firm TigerSwan; DAPL Security Operations Overview (DAPL Security Team, 2016); and an email thread from DAPL's intelligence group (Intel Group, 2016). I was guided by Bowen's (2009) and Triad 3's (2016) approaches to document analysis, which involves reading and re-reading texts, searching for words and passages relevant to my research problem(s), and analyzing these words/passages to elicit meaning for the problem, specifically of how settler state and fossil-fuel corporate institutions rationalize and practice dispossession of Indigenous lands. I read texts against theories of securitization and dispossession to elicit meaning. When reading, I searched for and observed the following three themes or rationales that were common to both Wet'suwet'en-Unist'ot'en and Standing Rock (albeit in different ways): illegality, "disruptions" to critical infrastructure and economy, and threats to private property. A rationale observed in the Wet'suwet'en-Unist'ot'en case (missing from Standing Rock) was divides between Indigenous governments and gaps in Indigenous title. Related to illegality, the Standing Rock case had a unique element of eliminating religiously motivated insurgency threats to the US state order. Following analyses of rationales in each case, I outline and analyze the security actions/strategies used by state and corporate institutions. I corroborate my analyses with sources such as advocacy organization reports, news articles, videos, and injunction analyses by Indigenous-led research institutes. To provide a broader account of the phenomenon beyond my analysis and theoretical perspective, I also supplement with opposing sources such as reports and briefings by multiple state agencies (i.e., the RCMP).

My document analysis is grounded in a combination of Marxist, decolonial, and comparative approaches. First, my research design is Marxist because I aim to understand how the surveillance and criminalization of Indigenous anti-pipeline resistance is rooted in processes relevant to accumulation by dispossession, wherein commonly held or stewarded resources are violently transferred to private ownership and capital accumulation by elite classes. Second, it is "decolonial" because I focus on how colonial, capitalist processes of dispossession impact Indigenous relations to lands, waters, and non-human nature, and I aim to increase awareness around this issue. Specifically, I analyze the colonial construct of CI, defined as a range of collectively assembled systems, networks, technologies, assets, facilities, and services necessary for the reproduction of human life, that if disrupted, can cause a loss of life and hinder the functioning of the economy and government (Mazer et al., 2019, p. 354; Spice, 2018, p. 40). Related to CI securitization is pacification, which Tia Dafnos (2013) defines as the "production of 
social relations and institutions in place of existing forms of social organization" (p. 59; emphasis in original). What is the relation between CI and pacification? Indigenous protest policing is rooted in logics/technologies of managing all life in terms of the "capacity to enable, filter, and obstruct mobilities and access to necessities, making some lives live and letting others die" (Dafnos, 2020, p. 116). Settler state and corporate actors have attempted to "pacify" Indigenous resistance through masking coercive power relations between the state/corporations and Indigenous Peoples and through "covert" repression (i.e., language of "engagement" with Indigenous rights) to appear progressive. My analysis involves tracing the extent to which the documents in both cases conform to Marxist and decolonial theories of dispossession, CI, and pacification. I connect my findings to such theories in order to illuminate the material, racial, and political implications of the security actions. Last, I used a comparative approach to draw out similarities and differences in the security institutional contexts in which the DAPL and CGL disputes are occurring.

\section{Findings: Rationales of Securitization}

To briefly provide context, in 2019, CGL won an injunction from the Supreme Court of British Columbia, ordering the Unist'ot'en Camp — established by members of the Unist'ot'en clan of the Wet'suwet'en First Nations to block the pipeline - to dismantle their blockade ( $C G L$ v. Huson, 2019). The Unist'ot'en Camp's goals include protecting community health, land, water, and sovereignty from the impacts of the 670-kilometer-long CGL pipeline (owned by TC Energy), carrying liquefied natural gas or "LNG" from Dawson Creek, BC, to an export terminal in Kitimat, BC (McCreary \& Turner, 2019/2018; Unist'ot'en Camp, 2017). Another key actor is the RCMP, the core policing agency responsible for enforcing the injunction, which raided Unist'ot'en Camp for failing to comply with the injunction (Brown \& Bracken, 2020). South of the border, the Standing Rock Sioux Tribe (and collectively, the "No Dakota Access Pipeline" or \#NoDAPL movement) has been, for five years, resisting the 1,886-kilometer-long, crude oil-carrying Dakota Access Pipeline (DAPL), owned by Energy Transfer Partners (ETP), LLC. DAPL moves half a million barrels of crude oil a day from the Bakken oil deposits in North Dakota, through South Dakota and Iowa, to a terminal in Patoka, Illinois (Estes, 2017). Key concerns mobilizing Standing Rock and \#NoDAPL include protecting treaty rights; protecting drinking water from potential oil spills; and opposing the violation, by the United States Army Corps of Engineers and ex-president Donald Trump, of 2016 orders by the Obama administration to halt and review (for environmental impacts) pipeline construction (Estes, 2017). A key security actor to consider for the Standing Rock case is TigerSwan, a US private security firm, reputed for its involvement in the post-9/11 "war on terror," that ETP hired for achieving the two-fold objective of protecting DAPL and surveilling and incapacitating \#NoDAPL, in collaboration with various law enforcement and security agencies.

In this section, I illustrate the rationales used by state and corporate security actors in the Wet'suwet'en and Standing Rock cases. I do this by introducing quotations from documents such as the BC Supreme Court injunction granted to CGL, TigerSwan Internal Situation Reports (SITREPs), and other DAPL-related surveillance reports. 


\section{Wet'suwet'en versus Coastal GasLink}

In passages from the injunction documents, "plaintiffs" refers to CGL, and "defendants" refers to Unist'ot'en Camp leader Freda Huson and Tsaiyex (Sun House) Hereditary Chief Smogelgem (Warner Naziel).

\section{Theme I: Illegality of Indigenous-led Direct Action}

The first rationale is that Indigenous land-defenders are acting "illegally" and disrupting the colonial legal order. Throughout the injunction document, it is evident that CGL is pushing for Indigenous-led direct actions to be managed and criminalized as "illegal activities." Two relevant passages from Justice Church's injunction illustrate this point:

The plaintiff submits that the defendants have chosen to engage in illegal activities to voice their opposition to the Pipeline Project, rather than to challenge the Pipeline Project by legal means. (CGL v. Huson, 2019, section 122, p. 28)

The plaintiff argues that an overriding principle that should guide the court's decision...is that the use of self-help remedies is contrary to the rule of law and is an abuse of process. The plaintiffs submit that where the defendant is obstructing lawfully permitted activity, recourse to self-help remedies cannot and should not be condoned by the court. (CGLv. Huson, 2019, section 123, p. 28)

\section{Theme II: "Disruptions" to CI and the Economy}

A second rationale of securitization was the protection of $\mathrm{CI}$ and the prevention of "threatening" economic and financial implications to CGL as a result of blockades.

\section{Figure 1}

CGL's "Irreparable Harm" Rationale: History of Cases 9. Given the illegality of the Blockade, irreparable harm is not required to grant the
injunction. Nonetheless, Coastal GasLink and others will suffer irreparable harm if the injunction
is not granted, including, but not limited to:

(a) Interference with an on-going business is harm within the meaning of the test for injunctive relief: A.J.B. Investments Ltd. v. Elphinstone Logging Focus, 2016 BCSC 734 at paras. 31-22; D.N.T Contracting Ltd. v. Abraham, 2016 BCSC 1917 at paras. 37 39 ("D.N.T."),

(b) Causing delays, which will result in increased costs to Coastal GasLink and others that the Defendants will not be able to compensate Coastal GasLink or its contractors for: Red Chris Development v. Quock, 2006 BCSC 1472; Trans Mountain Pipeline ULC v. Gold, 2014 BCSC 2133.

(c) Causing delays, increased costs and layoffs of employees: Red Chris; Council of the Haida Nation v. British Columbia (Forests, Lands, Natural Resource Operations and Rural Development), 2018 BCSC 1117 at para. 83.

Note. Retrieved from Section 9 of CGL's Notice of Application for Injunction (CGL v. Huson, 2018, p. 8) 
Figure 2

Examples of Blockade "Harms" cited by CGL

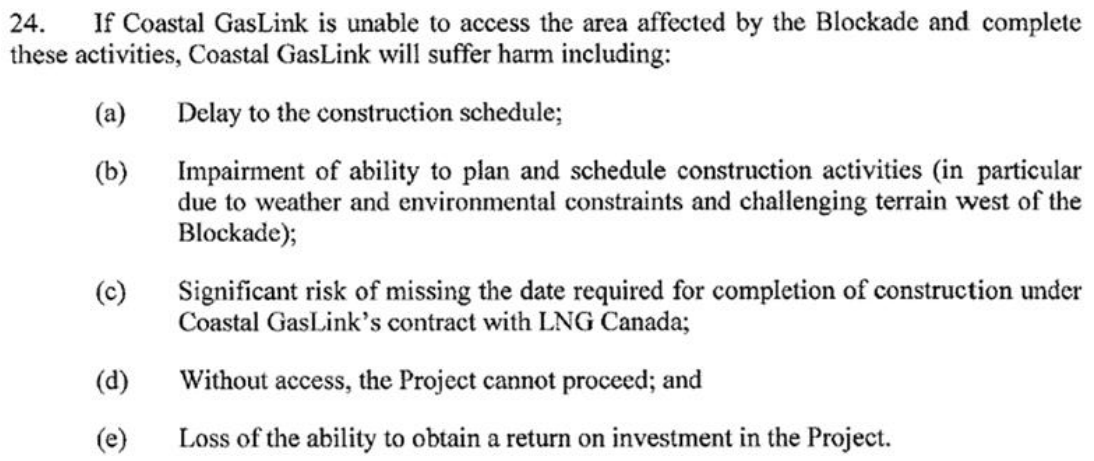

(a) Delay to the construction schedule;

(b) Impairment of ability to plan and schedule construction activities (in particular due to weather and environmental constraints and challenging terrain west of the Blockade);

(c) Significant risk of missing the date required for completion of construction under Coastal GasLink's contract with LNG Canada;

(d) Without access, the Project cannot proceed; and

(e) Loss of the ability to obtain a return on investment in the Project.

Note. Retrieved from Section 24 of CGL's Notice of Application for Injunction (CGL v. Huson, 2018, p. 5)

In the above passages, CGL outlines some specific material interests that it perceives to be threatened if the RCMP does not enforce an injunction and forcibly remove Unist'ot'en landdefenders from the pipeline construction path. In Section 9 (Figure 1), CGL supported its argument with past court cases involving what some have described as Indigenous and environmentalist movements crippling the economic and infrastructure development plans of companies in the oil and gas, forestry, and mining sectors.

\section{Theme III: Threats to Private Property}

A third rationale central to the injunction is that CGL's private property rights are supposedly "threatened" or "infringed" upon by the Unist'ot'en Camp. In the 2019 injunction, CGL supported its claim of private property rights "violations" on the following grounds:

Private nuisance is the interference with an occupier's use and enjoyment of land or property that is both substantial and unreasonable. The occupier need not hold title to the land or have exclusive possession in order to advance a claim for nuisance. The plaintiff has authorizations related to work on the Pipeline... arguably an interest sufficient to ground a claim in nuisance. (CGL v. Huson, 2019, section 167, p. 37)

\section{Theme IV: Divides between Indigenous Governments and Indigenous Title Gaps}

The fourth rationale prevalent in the injunction is that the Unist'ot'en Camp blockade, if left un-dismantled, will hinder First Nations' ability to receive economic benefits from CGL. To strengthen its argument for enforcing an injunction, CGL highlighted that 20 elected First Nation Band councils (whose authority is derived from the colonial-era 1876 Indian Act) signed agreements for pipeline benefits. Benefits emphasized by CGL include "approximately 2,500 jobs 
during peak construction [of CGL]," (Section 13 in CGL v. Huson, 2019, p. 4), over \$338 million in cumulative revenue to 20 First Nation Bands over the life of CGL, over $\$ 1$ billion in contract work and other opportunities for Indigenous and local businesses, and skills training and education. Meanwhile, the Office of the Wet'suwet'en (consisting of Hereditary Chiefs representing 12 of the 13 Wet'suwet'en Houses) and Dark House ${ }^{2}$ oppose the project and refused to meet with CGL and grant CGL an Environmental Assessment Certificate, despite "repeated attempts" by CGL to consult and negotiate agreements (CGL v. Huson, 2019, sections 60-61, p. 14).

In addition to exploiting divided opinion between different Wet'suwet'en governments, CGL aimed to build legitimacy by highlighting how the legal recognition of Wet'suwet'en law (by the colonial state) remains unrealized. As stated in the injunction,

There has been no process by which Wet'suwet'en customary laws have been recognized in this manner. The Aboriginal title claims of the Wet'suwet'en people have yet to be resolved either by negotiation or litigation. While Wet'suwet'en customary laws clearly exist on their own independent footing, they are not recognized as being an effectual part of Canadian law. (CGL v. Huson, 2019, section 128, p. 29)

There is no evidence before me of any Wet'suwet'en law or legal tradition that would allow blockades of bridges and roads or permit violations of provincial forestry regulations or other legislation. There is also no evidence that blockades of this kind are a recognized mechanism of dealing with breaches of Wet'suwet'en law. (CGL v. Huson, 2019, section 155 , p. 35)

\section{Standing Rock Sioux Tribe versus Dakota Access Pipeline}

Similar to state and corporate reactions to Wet'suwet'en resistance to CGL, state and corporate actors also rationalized their security efforts to curtail resistance to resource extraction. In this section, I introduce passages from TigerSwan SITREPs and other sources (i.e., DAPL Security Team, 2016).

\section{Theme I: Illegality—Religiously Motivated Insurgency Threats}

The first rationale observed in the Standing Rock case is that \#NoDAPL movement is an insurgent movement that threatens the American state and requires curtailment. As argued in TigerSwan's February 27, 2017 SITREP,

What the anti-DAPL protesters have called an "[I]ndigenous decolonization movement" was...an externally supported, ideologically driven insurgency with a strong religious component. And, as it generally followed the jihadist insurgency model while active, we can expect the individuals who fought for and supported it to follow a post-insurgency model after its collapse. (para. 1 in Porter, 2017, p. 4)

\footnotetext{
${ }^{2}$ Unist'ot'en House" or "Dark House" is one of the three "House groups" or matrilineages of the Gil_seyhu (Bull Frog) Clan of the Hereditary governance structure belonging to the Wet'suwet'en First Nations people (OOW, n.d.).
} 
The archetype of a jihadist post-insurgency is the aftermath of the anti-Soviet Afghanistan jihad. While many insurgents went back to their pre-war lives, many, especially the external supporters (foreign fighters), went back out into the world looking to start or join new jihadist insurgencies. (para. 2 in Porter, 2017, p. 4)

In addition to comparing Standing Rock and \#NoDAPL to "jihadist" insurgency of the past, TigerSwan did not hesitate to rule out the "possibility" of the movement having links to jihadist groups. As emphasized in the "Summary" section of TigerSwan's September 22, 2016 SITREP,

The presence of additional Palestinians in the [Red Warrior Camp, alongside Palestinian activist Haithem El-Zabri], and the movement's involvement with Islamic individuals is a dynamic that requires further examination. Currently, there is no information to suggest terrorist type tactics or operations; however, with the current limitation on information flow out of the camp, it cannot be ruled out. (Porter, 2016c, pp. 2-3)

Comparisons to post-Soviet Afghanistan and presumptions that involvement from Middle Eastern protestors opens a possibility of terrorism both illustrate that TigerSwan views \#NoDAPL as a threat to the order, security, and cultural foundations of American settler society.

\section{Theme II: "Disruptions" to CI and the Economy}

The second rationale evident in the Standing Rock case is the protection of the CI and economic interests of the fossil-fuel industry. According to the mission statement of the DAPL Security Team (2016), there are four main goals relevant to the surveillance of \#NoDAPL: "[P]rotect the contractors of DAPL, protect the machinery of DAPL, protect the material of DAPL, protect the reputation of DAPL and [their] individual sub-contractor companies" (p.1).

Additionally, some TigerSwan SITREPs contain references to CI and equipment being monitored by regular patrols and protected from "threats" by \#NoDAPL activists.

1. "More protestors cuffing themselves to construction equipment." ("Significant Events Last 12 Hours" in Porter, 2016b, p. 1)

2. "30-40 protestors on horseback attempted to ride toward the Ramberg Terminal...LE [Law Enforcement] reacted quickly and blocked access to the site." ("Past 24 Hours" in Porter, 2016e, p. 2)

3. "Continue to support worksites along ROW [Right-Of-Way] and static DAPL sites off the ROW." ("Next 24 Hours" in Porter, 2016e, p. 2)

\section{Theme III: Threats to Private Property}

The third rationale evident in the Standing Rock case was the "need" to protect the private property of DAPL from "trespass." According to TigerSwan's October 10, 2016 SITREP, 
Another large convoy involving nearly 100 vehicles and 200 people unfolded later in the day... where the protestors broke through security wire onto private property and immediately set about constructing a tipi on the ROW [Pipeline Right-Of-Way]. (Porter, 2016e, p. 1)

Similarly, the private property rationale was at play in TigerSwan's social media strategy. However, it took the form of TigerSwan denying any significant implications of DAPL upon territory with Indigenous jurisdiction. According to TigerSwan's September 13, 2016 SITREP, DAPL "sponsored" and promoted the following narratives:

"Pipeline is not being built on Native American land/reservation," and

" $99.98 \%$ of pipe is located on private land [and] 1094 feet [is] located under [federal property] at Lake Oahe. \#DAPL." ("Social Media Updates" in Porter, 2016a, p. 3)

\section{Discussion: Rationales of Securitization}

The Wet'suwet'en and Standing Rock cases shared three major similarities in rationale. First, settler state and corporate actors in both cases were motivated by the rationale that Indigenous resistance movements acted outside norms of legality and need to be managed to uphold state order. In the injunction granted to CGL, CGL grounds its argument on the basis that Unist'ot'en landdefenders chose to not challenge the project through "legal means," and that their peaceful assertions of title through direct action in construction pathways are illegal "self-help remedies." To connect to Monaghan's (2013) "Good vs. Bad Indians" concept, these arguments by CGL reflect rationales of instilling conformity to settler-colonial law and order, and of characterizing Indigenous groups who do not conform to settler-colonial legality norms as "threats." This is also observed in the Standing Rock case, but in a unique and more intense form. TigerSwan and various public law enforcement and security agencies (part of the Intel Group) attempted to link Standing Rock Water Protectors (and \#NoDAPL in general) with "jihadist" terrorism, a group which the US has historically targeted in its "war on terror" policies. (Recall the discussion on how Palestinian activists in solidarity with \#NoDAPL were ethnically profiled and monitored by TigerSwan, in Theme I of Standing Rock Sioux Tribe vs. DAPL.) Although the rationale of protecting settler-colonial order and norms of legality was important in both cases, and both American and Canadian security actors viewed such activists as "Aboriginal extremists" (Brake, 2018, para. 2), the RCMP did not associate Unist'ot'en with the same level of violent threat (from a particular religiously motivated terror organization) as TigerSwan did to Standing Rock.

Second, in both cases, settler-state and corporate institutions were motivated by the "need" to protect the CI of big oil. The CGL-requested injunction and multiple TigerSwan SITREPs prioritized protecting and patrolling construction sites, equipment, and facilities to prevent damage to and eliminate impediments to the technological networks that enable the export of oil and gas. In both cases, corporations sought legitimacy by highlighting the "catastrophic" impacts of pipelineshutdowns to workers and jobs. The way in which equipment and other pipeline infrastructures are portrayed in a neutral tone as benign, fixed, physical, and technical objects under threat, in both cases, obscures the hierarchical relations-between the state and Indigenous peoples, and between corporations and the environment - that produce (and are produced by) pipeline construction. For example, in Section 24 (Figure 2) of CGL v. Huson (2019), CGL covertly implied-through masking 
with language of "harm" suffered - that Indigenous resistance impedes activities that make politicaleconomic relations of capital accumulation possible and unmake Indigenous land relations. This reflects Dafnos's concept of pacification because CGL refers to infrastructure construction in a simplified manner as normal building activities, thus masking the contestations (between capital accumulation and Indigenous land relations) central to the pipeline.

A third similarity is that state and corporate actors were motivated by the need to protect private corporate property from being "trespassed" or removing obstacles to the enjoyment of such property. Although the overarching argument of protecting private property is manifested in both cases, we see an interesting contrast in how private property ownership was structured and rhetorically used to criminalize Indigenous resistance. In Section 167 (Theme III of Wet'suwet'en vs. Coastal GasLink) of CGL v. Huson (2019), CGL argued that Unist'ot'en blockades were interfering with its rightful enjoyment of private property, while also stating that it does not need exclusive title to Wet'suwet'en land: Under the Canadian land tenure system, the Crown "rents" out land to private companies (in this case, CGL) for resource extraction activities with rules and conditions (BC Oil and Gas Commission, 2013; Nelles, 2005). This reflects an interesting process of enclosure because CGL, while not "owning" the land, pushed the Court to criminalize Indigenous-led direct action on lands colonized by the state. Similarly, if we look at the Indigenous research think-tank Yellowhead Institute's analysis of 100 injunctions from 1970 to 2019 involving Indigenous Peoples in Canada, we see that $81 \%$ of the injunctions filed by private corporations against Indigenous Peoples were granted, while similar portions of injunctions filed by Indigenous Peoples (against corporations and the government) were denied (Yellowhead Institute, 2019). One could therefore argue that the policing of Unist'ot'en is part of a decades-long history of corporations using private property and other material interests to suppress Indigenous sovereignty through the court system. Meanwhile, TigerSwan, in grounding their claim that DAPL does not affect Indigenous land because over 99\% is on private lands (Porter, 2016a, p.3), ignored the Indigenous history of $99 \%$ of the lands of the pipeline route (where private property exists today). Regardless of how CGL and TigerSwan framed it, the private property argument works to criminalize Indigenous people for asserting sovereignty and resisting fossil-fuel extraction on their own territories. This is because the land title/rights of Indigenous peoples are erased or obscured in the corporations' rationales/framing and, as a result, normalizes what Coulthard and Kidd would call the enclosure (and ultimately, dispossession) of lands and waters for capital accumulation by big oil.

Despite the similarities, the cases also differed in rationale in one critical way. The Wet'suwet'en case was unique because settler state and corporate actors, in rationalizing security actions against land-defenders, appeared to "respect" Indigenous rights and jurisdiction. One way this was done was through exploiting divided opinion among the Wet'suwet'en Hereditary Chiefs (opposed to the pipeline) and elected band council chiefs (supporting the pipeline). Additionally, in Sections 128 and 155 (Theme IV of Wet'suwet'en vs. CGL) of CGL v. Huson (2019), CGL argued to the court that Indigenous title is not a valid defense because title is unresolved and "customary" and attempted to discredit Unist'ot'en by saying that there is no part of Wet'suwet'en law permitting infrastructural blockades (pp. 29, 35). Similarly, the RCMP's report on Project SITKA - a surveillance project on Indigenous "public order events" of resistance to resource extraction-recognized that Indigenous protests stem from unique, historical, and ongoing issues related to Indigenous land rights/claims, resource development, hunting rights, and more (RCMP, 2015, pp. iv-v). With that, we see the state employing Dafnos's concept of pacification because it presented itself as recognizing/respecting Indigenous rights, while masking the contestations and unequal power relations (between the state/corporations and Indigenous peoples) that are embedded in pipeline construction. In contrast, security documents related to Standing Rock indicate minimal to no engagement with Indigenous jurisdiction or sovereignty. Connecting these findings to prior literature from Plotnikoff (2020), this 
distinction between the use of pacification by Canadian security/corporations and the lack thereof in the US is noteworthy. Such a distinction potentially stems from the Canadian state's unique political position of balancing support for extraction with being an "Indigenous ally"; meanwhile, the US does not need to pursue this balance as it does not strive for a reconciliation image (Plotnikoff, 2020, p. 3).

\section{Findings: Strategies of Securitization}

Moving from a discussion on rationales, this section illustrates the security strategies that state and corporate actors utilized on the ground. Considering there is a dearth of publicly available security intelligence documents specific to the CGL case, I use evidence from sources such as briefing notes, civil society organization reports, and journalistic articles.

\section{Wet'suwet'en versus Coastal GasLink}

According to a secondary analysis of RCMP documents by Dhillon and Parrish (2019), the RCMP argued that lethal force is required and that arrests are necessary to "[sterilize] the site," and instructed their officers to "use as much violence toward the gate [blockade] as they want" (para. 35). Documents and social media videos also reveal that the RCMP and private security agencies tracked the movements of activists through techniques such as helicopter and airplane surveillance and descended upon Wet'suwet'en territories with attack dogs and assault rifles (Dhillon \& Parrish, 2019; Unist'ot'en Camp, 2020; Wet'suwet'en Access Point on Gidimt'en Territory, 2020). Furthermore, a note from a briefing document from the House of Commons Standing Committee on Public Safety and National Security (SECU) reveals that the RCMP established an access control checkpoint 27 kilometres away from the CGL construction zone to prevent protest camps from "blocking access" to construction sites. The RCMP also monitored and sought to "manage" various other "impediments" to the CI networks of the Canadian capitalist state, such as solidarity protests at shipping ports and railway tracks in BC, Manitoba, and Ontario (SECU, 2020, Tab 4-D, Background, paras. 4, 9). The RCMP was instructed to respond to questions (on their surveillance activities) by saying that they are doing this to prevent "escalations" of violence, maintain "public safety," and protect Canadian jobs, wellbeing, and the economy, among others (SECU, 2020, Tab 4-D, Proposed Response).

However, a January 2020 policy complaint to the RCMP by the BC Civil Liberties Association (BCCLA) - containing attached statements on the first-hand experiences of Indigenous land-defenders and journalists with the RCMP - exposes a dimension that RCMP public statements obscure. At the checkpoint, the RCMP prevented Wet'suwet'en supporters from delivering food and medicine supplies to activists, stopped drivers and passengers leaving and/or entering the checkpoint for identification checks, detained people for exiting the RCMP exclusion zone, and periodically denied (and later, allowed) access to BC journalists and legal observers (BCCLA, 2020, pp. 4-8).

\section{Standing Rock Sioux Tribe versus Dakota Access Pipeline}

Throughout its security operations, TigerSwan exchanged information on protestors with various law enforcement agencies such as state and local police departments and county police sheriffs (Brown et al., 2019). The following discussion reviews the surveillance strategies they used.

First, TigerSwan and other security agencies undertook "find, fix and eliminate" strategies that involved monitoring and "eliminating" \#NoDAPL as a potential "terrorist" threat. To recall "Findings: Rationales" (Theme I under Standing Rock Sioux Tribe vs. Dakota Access Pipeline), TigerSwan 
painted Water Protectors as undertaking strategies similar to a religiously and ideologically motivated "jihadist" insurgency model and did not rule out the potential that \#NoDAPL has ties to "Islamistmotivated" individuals (Brown et al., 2019, p. 198; Porter, 2016c). As detailed in a 24-page email thread from the Intelligence ("Intel") Group - which had seven members from FBI, Bureau of Indian Affairs, US Justice, and State and Local Intelligence Center-security officials used live video feeds from TigerSwan helicopter cameras to track the movements of activists. The four quotations below are emails in the Intel Group's email thread, sent by Bismarck, ND police officer Lynn Wanner on Nov 20, 2016 (Intel Group, 2016).

1. “Calling for 8 Humvees. Lit flairs are being launched from weapons." (Intel Group, 2016, p. 9)

2. “Officers are asking to retreat." (Intel Group, 2016, p. 10)

3. "Protestors firing flairs in the sky...Attempting to get over the wire using plywood." (Intel Group, 2016, p. 11)

4. "FBI inside source reporting propane tanks inside the camp rigged to explode." (Intel Group, 2016, p. 11)

Although it is possible that \#NoDAPL Water Protectors had flare guns and propane tanks, such devices were possibly used for peaceful purposes like safety and cooking, and we cannot claim with certainty that possessing such equipment signals a coordinated Indigenous-led attempt to destabilize security that warrants surveillance. The use of battlefield-like language, in this case phrases such as "retreat" and "rigged to explode," could potentially expose a sense of fear among security and police agencies that \#NoDAPL is a dangerous and violent "national security threat" (Brown et al., 2019, p. 205). Brown et al. also categorize such language use as "military language [verging] on parody" (p. 205), since the agencies are characterizing non-violent activists with military and tactical language better suited for counterterrorism operations in armed conflict zones.

Other avenues through which TigerSwan undertook "find, fix and eliminate" strategies included infiltrating activist circles and exploiting divides among the movement. For instance, TigerSwan officials used fake names/identities and engaged in "friendly" conversations to win over Water Protectors' trust, while others such as Silverton personnel played an "observational" role in Iowa protests (Brown et al., 2019, pp. 204-205; Porter, 2016a). TigerSwan argued that "[exploiting] ... ongoing native versus non-native rifts, and tribal rifts between peaceful and violent elements is critical in ... [efforts] to delegitimize the anti-DAPL movement" (Porter, 2016d, pp. 2-3). TigerSwan's exploitation of divides was racially charged, and this is evident when they incorrectly portrayed Indigenous activists, such as Kelly Hayes from the Menominee Tribe, as being part of a "Black Panther Party delegation" that supposedly engaged in violent "hand-to-hand combat training" (Juhasz, 2017; TigerSwan, 2016, p. 1).

Second, TigerSwan employed a social media engagement plan to influence the public narrative in favour of DAPL. This is evident in TigerSwan's September 22, 2016, report, which explicitly stated that its goals included "seeking out pro-DAPL propaganda and media" (Porter, 2016c, p. 4). This goal is evidenced by a TigerSwan employee's sharing of posts from Facebook pages "Netizens for Progress and Justice" and "Defend Iowa" - two pages critical of \#NoDAP — which were deleted after the news outlet The Intercept contacted TigerSwan (Brown et al., 2019, pp. 207-208). Other techniques that TigerSwan used for social media narrative-shifting included creating counter hashtags such as "\#DAPL" (Porter, 2016a), and spreading partial truths such as "99.98\% of [DAPL] is located on private land" in an attempt to discredit the \#NoDAPL Water Protectors (as alluded to in the Discussion: Rationales of Securitization). 


\section{Discussion: Strategies of Securitization}

Moving to a discussion of strategies, public and private security agencies in both cases utilized similar surveillance technologies. Those include aerial surveillance, monitoring activists' social media, and on-land surveillance such as through road checkpoints monitoring and/or blocking vehicles (especially those providing food and medical aid) entering and exiting Indigenous territories (BCCLA, 2020; Brown et al., 2019; Dhillon \& Parrish, 2019; King \& Munger, 2016). Additionally, the Wet'suwet'en and Standing Rock cases both highlight that the securitization of CI and the security tactics to suppress Indigenous resistance to fossil-fuel CI depend on collaboration and cooperation between state and corporate actors. In the context of Standing Rock, TigerSwan (surveillance corporation hired by DAPL) exchanged information with an "Intel Group" of numerous state institutions such as the FBI, Bureau of Indian Affairs, and local and state police departments. While TigerSwan was responsible for the intelligence gathering, police departments were responsible for arresting Water Protectors, and ETP-hired security guards used force, notably through the use of attack dogs. Similarly, in the context of Wet'suwet'en, we see the RCMP and CGL coordinating with one another to enforce an "anti-protest" checkpoint, and unnamed private security companies collaborating with the RCMP to surveil (through aerial means) Wet'suwet'en-Unist'ot'en land-defenders (Dhillon \& Parrish, 2019). However, three notable differences in strategy, and some limitations even in finding comparisons, must be considered.

One strategy seemingly absent from Wet'suwet'en, but present in Standing Rock, is the known use of infiltration tactics. While TigerSwan security agents befriended Water Protectors and activist circles and used fake names/identities to build trust, gather intelligence, and incapacitate \#NoDAPL, there is no evidence available on whether or how RCMP or any CGLhired private security firms infiltrated Unist'ot'en Camp or allied activist circles. A second strategy seemingly absent from Wet'suwet'en, but present in Standing Rock, is fossil-fuel companies and/or state security agencies using a deliberate and structured social media campaign to sway the public narrative in favour of pipelines. Third, Standing Rock is unique because TigerSwan exploited rifts between activists to support their security operations. TigerSwan utilized divides along the lines of race and difference in opinion among protestors, as highlighted in evidence of how Standing Rock Water Protectors were compared to Islamists/jihadists and the Black Panthers. Another relevant and interesting aspect was that TigerSwan-hired infiltrators used information on divides among Standing Rock Sioux Tribe members (e.g., tensions between Red Warrior Camp leader Tempeh and the Tribal Council) to attempt to discredit \#NoDAPL (TigerSwan, HUMINT, 2016). Meanwhile, there is no publicly available evidence on public or private security agencies exploiting divides among Wet'suwet'en pipeline opponents and their allies, in the CGL case.

Notwithstanding the research constraints involved with obtaining information about complex strategies in the recent and under-studied CGL case, such strategic distinctions could potentially stem from differences in the security and political contexts of Canada and the US. For example, if we connect the findings to Plotnikoff's (2020) research, the varying degrees of surveillance between the two cases and the battlefield-like tactics of TigerSwan could be influenced by US agencies' history of broadly categorizing environmental activists as "ecoterrorists," which is lacking in Canada (p. 34). Furthermore, TigerSwan's targeted surveillance of Black and Muslim Palestinian activists supporting \#NoDAPL, and its use of racial imageries 
describing them as potential violent threats, potentially stems from the US's history of targeting these specific groups both pre- and post-9/11 (Plotnikoff, 2020, p. 34). Last, through analyzing the strategic distinctions in light of Dafnos's concept of pacification, one could argue that perhaps CGL and Canadian security actors had no need to extensively target Wet'suwet'en-Unist'ot'en land-defenders as terrorists, nor use social media narrative-shifting, because the "pro-pipeline" forces were able to secure legitimacy for extraction through approval from band councils. From a security state standpoint, one could say that in the Wet'suwet'en context, the trust was "already won" from one Indigenous governing body (who supported due to economic reasons) and that the police did not need to earn their "opponents" trust to incapacitate them.

\section{Conclusion}

The aim of this study was to investigate how fossil-fuel extraction and the securitization of $\mathrm{CI}$ interact to further Indigenous land dispossession. This involved a combination of comparative and multiple theoretical analyses of documents related to Wet'suwet'en resistance to the CGL pipeline and Standing Rock resistance to the Dakota Access Pipeline (DAPL). Despite the nuances arising due to diverse contexts of experiences with colonialism, the Wet'suwet'en and Standing Rock cases involved shared rationales of securitization (by state/private actors) such as illegality, CI, and private property. However, the Wet'suwet'en case diverges in one critical way that relates to rationale: Fossil-fuel companies and security agencies made symbolic appeals to "honouring" Indigenous governance in order to secure legitimacy for both extraction and the policing of landdefenders. Although both cases involved similar surveillance methods and collaboration between the state and private sector, key strategic differences exist. Those include the presence of infiltration, social media narrative-shifting, and the exploitation of racial divides among activists, in the Standing Rock case.

Considering that recent Wet'suwet'en resistance to CGL is an under-studied research topic, and other shortcomings such as the time and privacy constraints of receiving information protected under the Access to Information Act (ATIA), publicly available information on all the security dynamics specific to this case is limited. First, further research is required on whether or how strategies of infiltration, narrative-shifting and/or racial divide-exploitation were at play in the Wet'suwet'en versus CGL case. Second, further research is needed on whether and how CGL and the RCMP (similar to DAPL, TigerSwan, and state agencies) exchanged surveillance-based intelligence with one another on Indigenous activists. 


\section{References}

Bowen, G. A. (2009). Document analysis as a qualitative research method. Qualitative Research Journal, 9(2), 27-40. https://doi.org//10.3316/QRJ0902027

Brake, J. (2018, Dec 3). Government document calls Unist'ot'en leader 'aboriginal extremist.' APTN. https://www.aptnnews.ca/national-news/government-document-calls-unistotenleader-aboriginal-extremist/

British Columbia Civil Liberties Association (BCCLA). (2020). Policy complaint concerning RCMP checkpoint on Morice West Forest Service Road [Email to Michelaine Lahaie, Chairperson, Civilian Review and Complaints Commission for the RCMP]. https://bccla.org/wp-content/uploads/2020/01/RCMP-Complaint-Public.pdf

British Columbia Oil and Gas Commission (BCOGC). (2013). Investigative Permit- Section 14 over Crown Land, Range 5, Coastal District within Unit 35 Block B, 103-I02 [File: 9638178; letter to Coastal GasLink]. https://www.bcogc.ca/files/projects/coastalgaslink/IUP_9638178_CGL.pdf

Brown, A., \& Bracken, A. (2020, Feb 23). No surrender: After police defend a gas pipeline over Indigenous land rights, protestors shut down railways across Canada. The Intercept. https://theintercept.com/2020/02/23/wetsuweten-protest-coastal-gaslink-pipeline/

Brown, A., Parrish, W., \& Speri, A. (2019). Counterterrorism tactics at Standing Rock. In N. Estes \& J. Dhillon (Eds.), Standing with Standing Rock: Voices from the \#NoDAPL movement (pp. 198-208). University of Minneapolis Press.

CGL v. Huson, BCSC (2018) Notice of Application for Injunction. http://forestaction.wdfiles.com/local-files/caravan/CGL\%20vs\%20Unistoten\%20injunction\%20application.pdf

CGL v. Huson, 2264 BCSC (2019). https://www.coastalgaslink.com/siteassets/pdfs/whatsnew/2019/2019-12-31-coastal-gaslink-comments-on-injunction-decision/judge-church-coastal-gaslink-pipeline-ltd.-v.-huson--december-2019.pdf

Coulthard, G. (2014). From wards of the state to subjects of recognition? Marx, Indigenous Peoples, and the politics of dispossession in Denendeh. In A. Simpson \& A. Smith (Eds.), Theorizing Native studies (pp.56-98). Duke University Press

Dafnos, T. (2013). Pacification and Indigenous struggles in Canada. Socialist Studies, 9(2), 5777. https://doi.org/10.18740/S49G6R

Dafnos, T. (2020). Energy futures and present threats: Critical infrastructure resilience, accumulation, and dispossession. Studies in Political Economy, 101(2), 114-134. http://doi.org//10.1080/07078552.2020.1802832 
DAPL Security Team. (2016, Oct 16). Security Operations Overview. The Intercept. https://theintercept.com/document/2017/05/27/security-operations-overview-2016-10-16/

Daly, R. (2005). Our box was full: An ethnography for the Delgamuukw plaintiffs. UBC Press.

Dhillon, J., \& Parrish, W. (2019, Dec 20). Exclusive: Canada police prepared to shoot Indigenous activists, documents show. The Guardian.

https://www.theguardian.com/world/2019/dec/20/canada-indigenous-land-defenderspolice-documents

Estes, N. (2017). Fighting for our lives: \#NoDAPL in historical context. Wicazo Sa Review, 32(2), 115-122. https://doi.org//10.5749/wicazosareview.32.2.0115

Fort Laramie Treaty, 1851, Cheyenne-Sioux-Arapaho-Crow-Assiniboine-Mandan-HidatsaArikara-Snake-Shoshone-Rees-Gros Venture-Ogala Sioux-Brule Sioux-U.S. Government, Sep. 17, 1851. https://www.nps.gov/scbl/planyourvisit/upload/Horse-CreekTreaty.pdf

Fort Laramie Treaty, 1868, Brule Sioux-Ogala Sioux-Miniconjou-Yanktonai-HunkapaBlackfeet-Cuthead-Two Kettle-Sans Arc-Santee-Arapaho-U.S. Government, AprilNovember 1868, 2 Indian Affairs: Laws and Treaties 997. https://americanindian.si.edu/static/nationtonation/pdf/Fort-Laramie-Treaty-1868.pdf

Harvey, D. (2005). A brief history of neoliberalism. Oxford University Press.

Howe, M., \& Monaghan, J. (2018). Strategic incapacitation of Indigenous dissent: Crowd theories, risk management, and settler colonial policing. Canadian Journal of Sociology, 43(4), 325-348. https://doi.org//10.29173/cjs29397

Intel Group. (2016, Nov 20). Email thread. The Intercept. https://theintercept.com/document/2017/06/03/intel-group-email-thread-2016-11-20/

Juhasz, A. (2017, Jun 1). Inside the military tactics used during Standing Rock. High Country News. https://www.hcn.org/articles/the-government-used-military-tactics-to-supressnodapl-activists

Kidd, D. (2020). Standing Rock and the Indigenous Commons. Popular Communication, 18(3), 233-247. https://doi.org//10.1080/15405702.2020.1781862

King, S., \& Munger, W. (2016, October 10). The surveillance state descends on the Dakota Access Pipeline Spirit Camp. American Civil Liberties Union (ACLU). https://www.aclu.org/blog/free-speech/rights-protesters/surveillance-state-descendsdakota-access-pipeline-spirit-camp 
Marx, K. (1976). Capital: A critique of political economy (E. Mandel, Ed., B. Fowkes, Trans.). Penguin Books, New Left Review. (Original work published 1867)

Mazer, K., Danyluk, M., Hunchuck, E., \& Cowen, D. (2019). Mapping a many-headed Hydra: Transnational infrastructures of extraction and resistance. In N. Estes \& J. Dhillon (Eds.), Standing with Standing Rock: Voices from the \#NoDAPL Movement (pp. 354-381). University of Minnesota Press.

McCreary, T., \& Turner, J. (2019; 2018). The contested scales of indigenous and settler jurisdiction: Unist'ot'en struggles with Canadian pipeline governance. Studies in Political Economy, 99(3), 223-245. https://doi.org//10.1080/07078552.2018.1536367

Monaghan, J. (2013). Settler governmentality and racializing surveillance in Canada's NorthWest. Canadian Journal of Sociology, 38(4), 487-508. https://doi.org//10.29173/cjs21195

Nelles, H.V. (2005). A frontier of monarchy. In The politics of development: Forests, mines, and hydro-electric power in Ontario, 1849-1941 (2nd ed., pp. 1-47). McGill-Queen's University Press.

https://books.google.ca/books/about/The_Politics_of_Development.html?id=N9DRjjxZR $\underline{\mathrm{PQC} \& \text { printsec }}=$ frontcover $\&$ source $=\mathrm{kp}$ read button $\&$ redir $\mathrm{esc}=\mathrm{y} \# \mathrm{v}=$ onepage $\& \mathrm{q} \& \mathrm{f}=\mathrm{fals}$ $\underline{\mathrm{e}}$

Office of the Wet'suwet'en, The (OOW). (2014). Wet'suwet'en Title \& Rights Report [submission to BC EAO and Coastal GasLink Pipeline]. https://projects.eao.gov.bc.ca/api/document/58868fd7e036fb010576878e/fetch/Wetsuwet en\%20Title\%20and\%20Rights\%20Report.pdf.

OOW. (n.d.). Wet'suwet'en Hereditary Chiefs House/Clan. http://www.wetsuweten.com/images/uploads/OrgChartWHC.pdf

Plotnikoff, E. (2020). Activists or active threats? How the state securitization of critical infrastructure impacts environmental and Indigenous activists in Canada and the United States [Unpublished master's thesis.] University of British Columbia. https://open.library.ubc.ca/collections/ubctheses/24/items/1.0394048

Porter, J. (2016a). DAPL SITREP 003, September 13, 2016 [Prepared for Energy Transfer Partners (ETP)]. The Intercept. https://theintercept.com/document/2017/05/27/internaltigerswan-situation-report-2016-09-13/

Porter, J. (2016b). DAPL SITREP 004, September 14, 2016 [Prepared for ETP]. The Intercept. https://theintercept.com/document/2017/05/27/internal-tigerswan-situation-report-201609-14/ 
Porter, J. (2016c). DAPL SITREP 011\#, September 22, 2016 [Prepared for ETP]. The Intercept. https://theintercept.com/document/2017/05/27/internal-tigerswan-situation-report-2016$\underline{09-22 /}$

Porter, J. (2016d). DAPL SITREP 022\#, October 3, 2016 [Prepared for ETP]. The Intercept. https://theintercept.com/document/2017/06/03/internal-tigerswan-situation-report-2016$\underline{10-03 /}$

Porter, J. (2016e). DAPL SITREP 019\#, October 10, 2016 [Redacted; Prepared for ETP]. The Intercept. https://theintercept.com/document/2017/06/03/internal-tigerswan-situationreport-2016-10-10/

Porter, J. (2017). DAPL SITREP 168, February 27, 2017 [Prepared for ETP]. The Intercept. https://theintercept.com/document/2017/06/21/internal-tigerswan-situation-report-2017$\underline{02-27 /}$

Royal Canadian Mounted Police (RCMP). (2015). Project SITKA: Serious criminality associated to large public order events with national implications 2015/03/16 (File No. 20131509123). https://warriorpublications.files.wordpress.com/2016/11/project-sitkareport.pdf

SECU, House of Commons Standing Committee on Public Safety and National Security. (2020). Standing committee on Public Safety and National Security - Supplementary estimates B [Briefing note]. https://www.rcmp-grc.gc.ca/en/standing-committee-on-public-safetyand-national-security-supplementary-estimates-b?wbdisable=true\#a4a

Spice, A. (2018). Fighting invasive infrastructures: Indigenous relations against pipelines. Environment and Society, 9(1), 40-56. https://doi.org//10.3167/ares.2018.090104

Temper, L. (2019). Blocking pipelines, unsettling environmental justice: From rights of nature to responsibility to territory. Local Environment: Environmental Justice and Epistemic Violence, 24(2), 94-112. https://doi.org//10.1080/13549839.2018.1536698

TigerSwan. (2016). DAPL SITREP 058\#, November 9, 2016 [Redacted Report]. https://assets.documentcloud.org/documents/3762268/SITREP-058-11-9-16Redacted.pdf

TigerSwan, HUMINT. (2016, Dec 8). TigerSwan at Standing Rock: Daily HUMINT Reporting for December 8, 2016. https://www.documentcloud.org/documents/7328404-TigerSwanat-Standing-Rock-Daily-HUMINT.html

Triad 3. (2016, March 9). An introduction to document analysis. Research methodology in education. https://lled500.trubox.ca/2016/244 
Unist'ot'en Camp. (2017). No pipelines- Background of the campaign. https://unistoten.camp/no-pipelines/background-of-the-campaign/

Unist'ot'en Camp. (2020, Feb 1). RCMP aerial surveillance at Unist'ot'en camp [Facebook status update and video]. https://fb.watch/8K6jZKftpN/

Wet'suwet'en Access Point on Gidimt'en Territory. (2020, Feb 6). Militarized RCMP raid Gidimt'en monitoring post at 39KM [Facebook status update and video]. https://fb.watch/8K6PLvonBc/

Yellowhead Institute. (2019). A review of over 100 injunction cases involving First Nations across Canada. https://redpaper.yellowheadinstitute.org/wpcontent/uploads/2019/11/injunctioninfographics.pdf?fbclid=IwAR2jbzXTs8Ma1oAuxGWHcYA54cEcYZGnNot4wRwK7cnO5a9fVD3JCSEV4Q 